\title{
In search of the transcriptional blueprints of a competent oocyte
}

\author{
Rolando Pasquariello ${ }^{1,2, *}$, Vittoria Bocchi ${ }^{3, *}$, Tiziana A.L. Brevini ${ }^{4}$, Fulvio Gandolfi, \\ ${ }^{1}$ Colorado Center for Reproductive Medicine, Lone Tree, CO, USA. \\ ${ }^{2}$ Colorado State University, Department of Biomedical Sciences, Fort Collins, CO, USA. \\ ${ }^{3}$ Laboratory of Stem Cell Biology and Pharmacology of Neurodegenerative Diseases, Department of Biosciences, \\ University of Milan and Istituto Nazionale di Genetica Molecolare, Milan, Italy. \\ ${ }^{4}$ Department of Health, Animal Science and Food Safety, Università degli Studi di Milano, Italy. \\ ${ }^{5}$ Department of Agricultural and Environmental Sciences, Università degli Studi di Milano, Italy.
}

\begin{abstract}
The oocyte undergoes a remarkably long and elaborated journey within the follicle before becoming fully equipped to sustain embryonic development. Its ability to support early embryonic development relies largely on the maternal transcripts accumulated during its growth and maturation. However, it is still not clear what transcriptome blueprint composes a competent oocyte. A number of extensive studies provided a detailed characterization of the mRNA molecules that are gradually accumulated in the oocyte cytoplasm. The detail of our knowledge has gradually increased through the years also thanks to the development and improvement of the analytical techniques. From realtime PCR analysis of single transcripts, to the whole transcriptome approach of gene arrays and new genereation sequencing, scientists accumulated an exponentially growing amount of new information. More recently, the discovery of non-coding RNAs revealed a new layer of complexity in the mechanisms that modulate gene expression at the mRNA level, in folliculogenesis and oogenesis. In particular, data are emerging on the potential role of microRNAs in controlling ovarian function, oocyte maturation and the oocyte-somatic cell cross talk. This review will try to summarize the vast amount of data currently available on the mRNAs and microRNAs associated with the ovarian function and to find their biological significance.
\end{abstract}

Keywords: oocyte, competence, folliculogenesis, transcriptome.

\section{Introduction}

A complex spatio-temporal interaction of several metabolic pathways strictly regulates folliculogenesis and oogenesis, which contributes to the gradual acquisition of the oocyte developmental potential. These mechanisms dictate how recruitment, selection and growth of the follicles take place, and how atresia, ovulation, and corpus luteus formation follow. All these process occur in the ovary and are dependent on the precise expression and interaction of several intra- and extra-ovarian factors, which work both in an autocrine and paracrine manner. Moreover, the growth and development of mammalian oocytes is critically dependent on a bidirectional communication between the oocyte and its companion somatic cells (Banerjee $e t$ al., 2014). Follicle development, in fact, consists of the sequential differentiation of the oocyte and its surrounding somatic cells, which form the granulosa and theca layers (Knight and Glister, 2001).

It is well known that folliculogenesis starts with the activation of resting follicles and gradually leads to the growth and development of a pre-ovulatory follicle (Knight and Glister, 2001). The process takes place through different phases beginning with recruitment that consists of primordial follicles that become primary follicles and develop up to $2 \mathrm{~mm}$ in diameter. This is followed by selection and growth of small and mid-antral follicles, leading to an $8 \mathrm{~mm}$ diameter. Ovulation of the pre-ovulatory dominant follicle, with a diameter larger than $8 \mathrm{~mm}$, takes place together with the degeneration of unovulatory subordinate follicles, which undergo through follicular atresia. These phases take place in a wave-like progression, with typically 2 or 3 follicular waves per estrous cycle in cattle (Fortune et al., 1991; Adams, 1999). The overall process takes from several weeks to a few months depending on the species (Fig. 1). Although other species will be mentioned as well, in this review we will refer mainly to cattle.

The first and longest phase of oocyte development takes a few months and covers from the primordial follicle up to the antral/tertiary follicle. During this time the inside diameter of the gamete increases from less than $30 \mu \mathrm{m}$, in the quiescent primordial follicle, to more than $120 \mu \mathrm{m}$ in the tertiary follicle. The second phase is the progress of the oocyte in the dominant follicle, a process lasting for one to two weeks. This phase is referred to as "oocyte capacitation" (Hyttel et al., 1997). The last phase is the oocyte maturation, and takes place in the ovulatory follicle during the approximately $24 \mathrm{~h}$ long period, between the peak of the LH surge and just before ovulation.

During its growth, the oocyte develops what is called "developmental competence" that refers to the oocyte ability to produce normal, viable and fertile offspring after fertilization. Developmental competence is usually expressed as the percentage of oocytes that can develop to the blastocyst stage (Gandolfi et al., 1998a). It has been shown that follicle size, oocyte diameter and oocyte competence are closely linked. In cattle, follicles with a large diameter contain oocytes with higher developmental potential (Gandolfi et al.,

\footnotetext{
${ }^{6}$ Corresponding author: fulvio.gandolfi@unimi.it

*Equally contributed to the preparation of this manuscript 
1998b). Studies have proved that bovine oocytes collected from presumptive dominant follicles $(>13 \mathrm{~mm})$ yield a significantly higher blastocyst rate, compared with oocytes obtained from follicles of 3 to $8 \mathrm{~mm}$ (Hagemann et al., 1999). However, other factors besides follicular should be considered since some large follicles contain developmentally incompetent oocytes while, some medium follicles contain competent oocytes (Blondin and Sirard, 1995). Ovarian morphology is another parameter used to estimate the developmental competence of the oocyte. It has been shown that, oocytes retrieved from ovaries that have at least one follicle larger than $10 \mathrm{~mm}$ in diameter, or with more than 10 follicles of 2 to $5 \mathrm{~mm}$, have a higher developmental potential (Gandolfi et al., 1997). Therefore, the number and size of the follicles present in the ovary at the time of aspiration may be used to select oocytes with higher developmental competence.

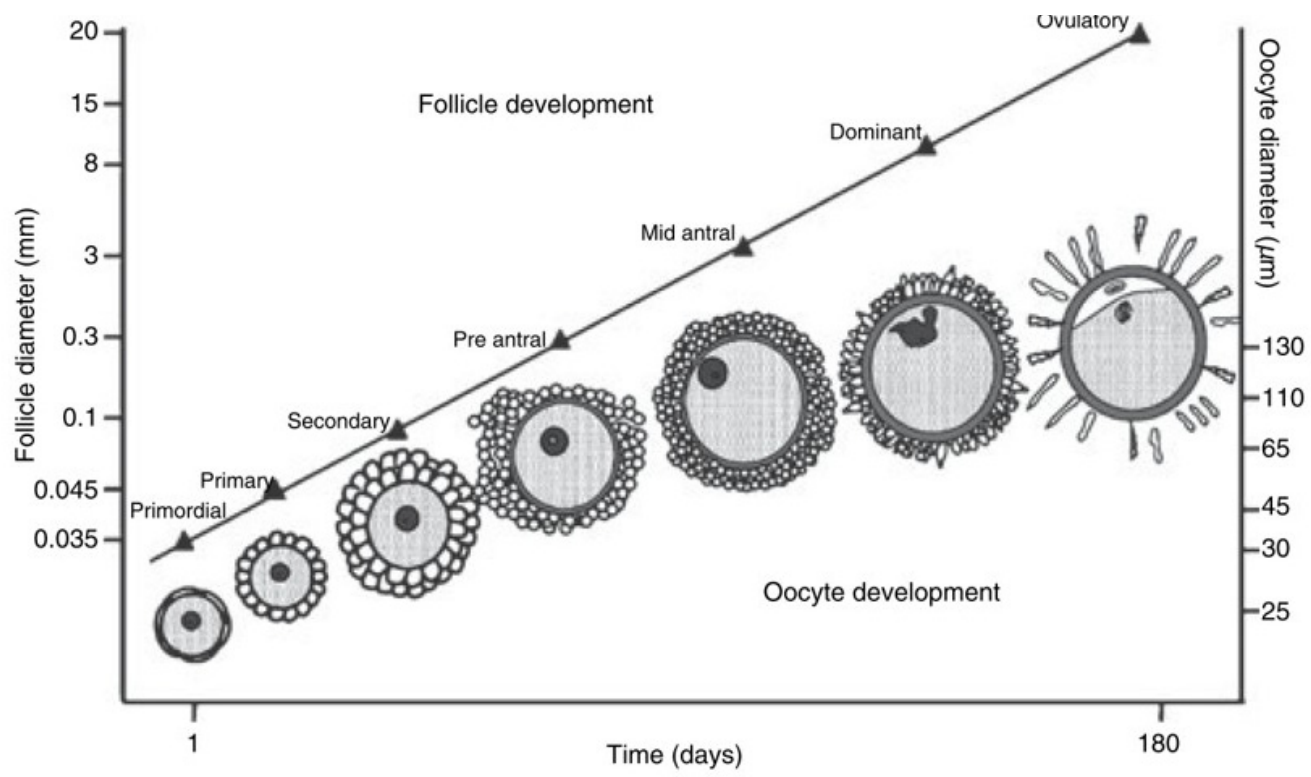

Figure 1. Folliculogenesis in cattle. The evolution from primordial to preovulatory follicles takes up to six months, depending on the species considered. During this period, both the oocyte and the follicle undergo remarkable and complex changes, which are indispensable for the formation of a competent oocyte.

The knowledge of the regulation of gene expression at the level of mRNAs in oocyte and early embryo has improved as the technology available has advanced. It is now well known that the maternal contribution has a large impact on early embryo development. Indeed, maternally derived mRNAs present in the oocyte decrease rapidly following fertilization (Milazzotto et al., 2012) but the lack of some maternal mRNAs can determine a low oocyte competence and quality (Labrecque and Sirard, 2014). However, the detailed molecular mechanisms affecting oocytes developmental competence are unknown. It has been shown that it is the final period of oocyte growth where developmental potential is mostly acquired in humans (Sorensen and Wassarman, 1976), mice (Gougeon, 1986) and cattle (Sirard et al., 2006).

Recently, another class of RNAs, the small non-coding RNAs, has been associated with folliculogenesis and oogenesis. Small non-coding RNAs are post-transcriptional regulators of gene expression, which range in size from 18 to 32 nucleotides (nt). They are generally divided into three functional classes: microRNAs (miRNAs), endogenous small interfering RNAs (endo-siRNAs) and Piwi-interacting RNAs (piRNAs; Babiarz et al., 2008; Kim et al., 2009; Thomson and Lin, 2009; Juliano et al., 2011; Ishizu et al., 2012). Among small RNAs, interest has focused on miRNAs (miRNAs) for their property to regulate gene expression at the mRNA level. They are found in the diverse compartments of ovarian follicles, including granulosa cells (Hatzirodos et al., 2014a), theca cells (Hatzidoros et al., 2014b), follicular fluid and oocytes (Bonnet et al., 2008). Studies demonstrated their role in follicle development of humans (Sirotkin et al., 2009; Sang et al., 2013; Roth et al., 2014), mice (Fiedler et al., 2008; Carletti et al., 2010), cattle (Tesfaye et al., 2009; Ma et al., 2011; Sohel et al., 2013), pigs (Lin et al., 2012; Donadeu and Schauer, 2013) and horses (Da Silveira et al., 2012). Data suggest that miRNAs may regulate cellular differentiation during follicular development and may contribute to the oocyte-somatic cells dialog during the acquisition of oocyte developmental competence. In cattle, miRNAs were found in follicular fluid and their profile changes during folliculogenesis (Zielak-Steciwko et al., 2014). They are both free and associated with exosomes; the latter possibly facilitating the transport of specific miRNAs into follicular cells (Sohel et al., 2013).

This review will attempt to summarize the current knowledge on mRNAs and miRNAs associated with a correct folliculogenesis and oogenesis processes. It will also discuss which mRNAs and miRNAs are more likely to play a critical role in determining oocyte competence.

\section{The pathway towards oocyte competence}

The oocyte goes through three phases of maturation to become developmentally competent. 


\section{Meiotic maturation}

Meiotic maturation is the cascade of nuclear events triggered, in vivo, by the pre-ovulatory LH surge or, in vitro, by the removal of the oocyte from its follicular environment. Either one of these signals activate the maturation promoting factor (MPF), a protein complex composed of cyclin B1 and P34 ${ }^{\text {cdc2 }}$, that, in turn, activates the cell cycle machinery that drives the oocyte through the first metaphase (MI) and the extrusion of the first polar body. Meiosis progresses until the cytostatic factor (CSF) arrests the process, after the formation of the second metaphase (MII; Sirard et al., 1989). Meiotic competence is the capacity of the oocyte to complete meiosis by undergoing through germinal vesicle breack-down (GVBD) and chromosome condensation. The acquisition of full meiotic competence in bovine oocytes coincides with the reduction of the nucleolar transcriptional activity (Fair et al., 1997). Growing oocytes can be categorized as incompetent or competent to resume meiosis (Arlotto et al., 1996). Incompetent bovine oocytes remain at the germinal vesicle $(\mathrm{GV})$ stage because they do not have enough cyclin $\mathrm{B}$ to progress beyond prophase I (Levasque and Sirard, 1995). Meiotic competence is related to the diameter, a high proportion of bovine oocytes are able to resume meiosis to the MI stage once their diameter is at least $100 \mu \mathrm{m}$. However, the oocyte must measure $110 \mu \mathrm{m}$ or more to reach the MII stage (Fair et al., 1995).

\section{Cytoplasmic maturation}

Cytoplasmic maturation describes the ultrastructural changes that take place in the oocyte from the GV to the MII stage. Different organelles move during cytoplasmatic maturation: the germinal vesicle is eccentrically located in bovine oocytes with a diameter smaller than $110 \mu \mathrm{m}$, whereas in oocytes with a diameter greater or equal to $110 \mu \mathrm{m} \mathrm{GV}$ is located close to the zona pellucida (Fair et al., 1995). Mitochondria are centrally located in oocytes with a diameter smaller than $100 \mu \mathrm{m}$, but move to the periphery in oocytes larger than $110 \mu \mathrm{m}$ (Fair et al., 1995). Mitochondria are necessary to produce adenosine triphosphate (ATP), which is necessary for several functions, including motility, maintenance of homeostasis, and regulation of cell survival. Therefore, migration of active mitochondria across the cytoplasm is necessary in order to achieve full developmental competence (Brevini et al., 2005). Cortical granules also change location through cytoplasmatic maturation. They are initially located in the center of the oocyte, but as the oocyte progresses to the MI stage, cortical granules translocate to the periphery and become attached to the plasma membrane (Cran, 1989).

\section{Molecular maturation}

Specific mRNAs are produced and added to the oocytes stockpile during molecular maturation. In cattle, oocytes transcriptional activity of the maternal genome starts at the secondary follicle stage with the synthesis of both heterogeneous nuclear RNA (the precursor of messenger RNA) and ribosomal RNA. Thereafter it increases when the diameter of the oocyte reaches around $80-100 \mu \mathrm{m}$, but then gradually decreases while it growth to $110 \mu \mathrm{m}$ and then slows to an almost complete arrest when the oocyte is fully grown around $120 \mu \mathrm{m}$ (Hyttel et al., 2001). The nucleolus also changes its morphology from fibrillo-granular with loosely compacted chromatin to dense fibrillar and compacted chromatin, as the oocyte gets closer to ovulation (Fair et al., 1996). These transcripts are necessary to guide the early stages of embryonic development prior to the activation of embryonic transcription, which is not robustly activated until the 8 to 16 -cell stage. The maternal mRNA population is highly diverse, and supports a range of different functions during oocyte maturation and after fertilization. Studies have shown that maternal transcripts are involved in pronuclear formation and fusion (Philipps et al., 2008), the first cell division (Tang et al., 2007), embryonic gene transcription (Bultman et al., 2006) and cleavage-stage embryogenesis (Ma et al., 2006).

The maternal mRNA recruitment is not chaotic, but rather seems to follow a very carefully orchestrated patter (Brevini et al., 2007). In particular, specific sequences located in the untranslated region (UTR) of the 3' end of the mRNA molecule regulate mRNA stability, control translational activation and repression and direct mRNA localisation. A study (Brevini and Gandolfi, 2001) showed that regulation of maternal mRNA translation is based on changes in the length of the poly(A) tail of the mRNAs. Oocyte mRNAs with short poly(A) tails are translationally inactive and are activated upon extension of the tail during specific stages of embryo development. Another study (Brevini et al., 1999) showed a relationship between the extent of polyadenylation, mRNA stability and the state of competence. In fact, oocytes that have not yet achieved full competence contained mRNA strands with shorter poly(A) tails than fully competent oocytes.

Studies in mice show that also miRNAs have an important role in modultating a large proportion of maternal mRNA expressed during oogenesis and early embryo development (Tang et al., 2007). Maternal transcript translation, in fact, is inhibited by either degradation or block of translation when miRNAs bind to the 3' UTR of target mRNAs. A study showed that 59 miRNAs are differentially expressed during bovine oocyte maturation in vitro and a selection of these showed a distinct temporal expression pattern during preimplantation embryonic development (Tesfaye et al., 2009)

\section{Obstacles and pitfalls along the pathway to competence}

Transcripts accumulated during oocyte maturation play a pivotal role in determining the fate of the future embryo and any perturbation of this delicate process is likely to reduce oocyte developmental competence and cause an arrest of embryonic 
development. However, another critical point to consider is the time taken by the oocyte to acquire its developmental competence. As mentioned above, oocyte development takes a few months and several factors can influences the process along this crucial period, causing stress to the oocyte and reducing its quality. Several studies have shown, for instance, that environmental chemicals are able to significantly impact oocyte ability to support development (Pocar et al., 2006). Another main influence results from dietary changes that can cause an immediate alteration of the maternal milieu where the oocyte grows. For example, oocytes recovered from dairy cows with a low body conditioning score (BCS) due to under nutrition showed reduced in vitro cleavage and blastocyst formation rate compared to oocytes collected from cows with a good BCS (Snijders et al., 2000). The observation that high yielding cows, have a low reproductive performance, as a consequence of the period of negative energy balance (NEB) during lactation (Leroy et al., 2008) further confirms the role of nutrition. The general consensus indicates that the lower fertility in lactating dairy cows suffering metabolic disorders may be due to the stress caused to the developing oocyte. In vitro studies simulated this kind of metabolic stress by exposing oocytes to elevated concentrations of non-esterified fatty acid (NEFA) during maturation. Results indicated that NEFA altered oocyte energy metabolism, up regulating the expression of genes that encode enzymes involved in REDOX regulation, leading to an imbalanced intracellular REDOX potential. Embryos originated from oocytes exposed to high NEFA levels had a significantly lower cell number and an increased apoptotic cell index (Van Hoeck et al., 2013). However, also high-energy diets may have adverse effects during the acquisition of oocyte developmental competence (Rooke et al., 2009). Supplementary dietary carbohydrates in high-yielding dairy cows, reduced oocyte quality and embryo development giving a lower blastocyst rate with fewer cells per embryo (Fouladi-Nashta et al., 2005).

Another fundamental element to consider is heat stress: for example, thermal stress increases the variation in the membrane fatty acid profiles and this is associated with reduced oocyte developmental competence (Zeron et al., 2001). Heat stress has also a general effect altering the transcriptional levels of genes involved in oogenesis, folliculogenesis and embryonic development (Gendelman and Roth, 2012).

\section{The analysis of oocyte transcriptome: from single gene to whole genome}

The development of new technologies for the analysis of gene expression (both mRNAs and miRNAs) and the improvement of reproductive biotechnologies have changed the approaches to study the biology of gametes and early embryos, including oocyte, spermatozoa and blastocyst. In cattle, pioneer studies on gene expression of oocyte competence analyzed the relative or absolute abundance of selected genes using Real Time PCR (RT-PCR; Brevini et al., 2002; Lonergan et al., 2003; Mourot et al., 2006). This is still a robust methodology for the analysis of both RNAs and miRNAs and the method of choice to validate the results of high throughput methods that have been developed more recently. These include chip arrays and deep sequencing that allow the analysis of large portions or of the entire transcriptome present in a sample. Thanks to these and analogous techniques current studies have embraced the "omic" approach, which includes transcriptomics, proteomics and metabolomics.

Array chips are assembled spotting thousands of pre-selected genes so that their expression can be simultaneously assessed in any given sample. Examples are the Atlas human cDNA arrays (Dalbiès-Tran and Mermillod, 2003) or specie-specific gene sets such us the EmbryoGENE bovine transcriptomic platform (Labrecque et al., 2015, 2016). The application of this approach to the ovary enabled to profile the expression of sets of selected genes, in the different compartments of the ovarian follicle, including theca and granulosa cells (Labrecque and Sirard, 2014). Furthermore, latest developments make it possible to analyze very small samples, including a single polar body separated from a mature oocyte, or to compare the mRNA contents of oocytes matured in vivo or in vitro.

Several platforms of chip arrays enable the analysis of miRNAs as well. In cattle these chip arrays were used to characterize the expression of miRNAs in the oocyte (Tesfaye et al., 2009), ovarian follicle (Sontakke et al., 2014) and cellular components of the ovarian follicle, including theca and granulosa cells (Abd El Naby et al., 2013; Zielak-Steciwko et al., 2014). Since miRNAs are found also outside the cells, interesting resuts were obtained analyzing the follicular fluid, whose miRNA content has been linked to the oocyte growth and may represent potential biomarkers of developmental competence (Sohel et al., 2013). As opposed to gene arrays for the analysis of mRNA molecules, commercial miRNA arrays are less limited by a use across different species. For example, bovine miRNAs include also known or predicted miRNAs from other species such as human and mouse (Mondou et al., 2012). This is possible because miRNA sequences are highly conserved in mammals (i.e. human miRNA sequences are homologous to the complete bovine sequences).

The advent of deep sequencing, both of mRNAs and small RNAs, has allowed the analysis of the entire transcriptome and miRNome expressed by any given cell type or tissue without the need of a specific a priori knowledge of the transcripts that might be present in the sample of interest. The substantially new characteristic of deep sequencing is that all mRNAs and miRNAs expressed in the sample are identified at the end of the procedure during the process of annotation and discovery of data analysis, the so called bioinformatics pipeline. This means that the results are no more determined by the transcripts that we were expecting to find and therefore were spotted on the array. Instead, this new technology allows the identification of any given sequence, even if totally unexpected, in a specific sample. The only limitation is 
the degree of annotation of the reference genome, which depends on the species of interest (Trapnell et al., 2009, 2010; Friedlä nderet al., 2012; Kozomara and GriffithsJones, 2014).

The technique can also be applied to gametes and embryos, although these must be analyzed in pools due to the low amount of available RNA quantity as the starting material (Antoniou and Taft, 2012; Graf et al., 2014). However, the new era of RNA sequencing aims to the single cell analysis thanks to an amplification step before library preparation, recent examples of which are available in cattle too (Chitwood et al., 2013; Reyes et al., 2015).

Small RNA sequencing of gamete and embryos is still a challenge since amplification procedures before library preparation, are still unreliable. Thus, high amounts of RNA and small RNA samples are needed, as reported by Gilchrist et al. (2016), who performed the profiling of miRNA populations using pools of more than 600 Germinal Vesicle oocytes, MII oocytes, and presumptive zygotes. However, we have recently developed a protocol that enabled small RNA seq using pools of only 30 embryos (Pasquariello et al., 2016a) that should enable an easier application of this technique to small samples. The amount of starting material is not a limiting factor for abundant and easy to collect samples like granulosa cells (Gebremedhn et al., 2015). Therefore the role of granulosa cell miRNAs on oocyte growth and maturation has been studied both in vivo and in vitro, including the validation of their mRNA targets (Andreas et al., 2016; Gebremedhn et al., 2016).

A feature common to both array chips and deep sequencing is the huge amounts of data generated at the end of each experiments. In order to understand which of these data have a functional significance it is necessary to validate each gene by RT-PCR. For practical reasons often linked to limited biological material and economical resources, such validation is limited to a very small subset of mRNAs and miRNAs. Thus, many information are gradually lost during the different steps of bioinformatics analysis, as scientist tend to focus gradually only on fewer and fewer genes. Therefore, the final evolution of the methods used to understand folliculogenesis and oogenesis must include an increasing ability to share and compare data of metabolic pathways and gene networking, gathered by different studies. The first meta-analyses of different bovine datasets have recently been published. One describes the transcriptome changes of bovine granulosa cells under different physiological conditions, obtained using the same platform (Khan et al., 2016). Another compared the gene expression profile among 10 different bovine tissues collected from nearly 200 animals, in the attempt to identify what contributes to determining the outcome of the function of individual tissues (McGettingan et al., 2015).

\section{Roles of mRNAs in ovarian function and oocyte competence}

Mammalian oocyte growth and maturation consists in the accumulation of both maternal RNAs and proteins (Telford et al., 1990). These constitute the hallmark of the oocyte which is its high level of transcription, driven by maternal mRNAs, together with its stored proteins that are crucial for the early development of the newly fertilized zygote (Wassarman and Kinloch, 1992). Therefore, maternally inherited components stored within the oocyte regulate the early stages of embryogenesis. As development proceeds, the process of early embryogenesis becomes gradually dependent on the expression of genetic information from the embryo (Telford et al., 1990).

Storage of mRNA during oocyte maturation, and its timely availability during early embryo development, is essential for oocyte quality and developmental competence. There is differential expression of transcripts between in in vitro matured and immature bovine oocytes, which underlines the tight temporal control of protein synthesis required for oocyte maturation in preparation for subsequent fertilization and early embryonic development (Fair et al., 2007).

Oocyte competence is selected based on different morphological criteria that range from follicle size to chromatin configuration (Labrecque and Sirard, 2014). Different groups have tried to pinpoint the transcriptome blueprint of a competent oocyte according to these known biological markers. Starting from follicle size it is well known that oocytes from large follicles are generally considered more competent and have a higher probability of researching the blastocyst stage. Gene expression according to follicle size has been measured in cattle by microarray analysis (Labrecque, et al., 2016). The study showed a few differentially expressed genes between oocytes from small follicles $(<3$ vs. $3-5 \mathrm{~mm})$, whereas an important number of differences were detected between oocytes from larger follicles $(5-8$, and $>8 \mathrm{~mm})$. Larger follicles possessed a stockpile of mRNA involved in transcriptional regulation, chromatin remodeling energy production as well as transport of key molecules within the cell. The mRNAs differences identified between the two larger follicles classes may represent the essential package of transcripts necessary to identify a competent oocyte. The acquisition of competence has also been analyzed in murine models by paired comparisons of the transcriptome of mouse oocytes collected from follicles at the primordial and primary, primary and secondary, secondary and small antral, and small antral and large antral stages (Pan et al., 2005). This study illustrates how the stack of transcripts changes during oocyte maturation and, therefore, illustrates the ideal acquisition of the correct mRNA package. The largest degree of change in gene expression occurred during the primordial to primary follicle transition. Surprisingly, $60-65 \%$ of the transcripts decreased in abundance as the follicle grew, which was an unexpected result as one may predict a gradual increase in mRNA content as the follicle matures and the oocyte reaches competence. The overexpressed genes were involved in DNA repair and response to DNA damage, which reflects the importance of high quality DNA in the oocyte so that it can pass on an intact genome to the embryo upon fertilization. 
Another classical identifier of oocyte competence is the ovarian phase of follicular development. Oocytes collected during the growth phase of follicular development are of better quality than those collected during the dominance phase, due to the negative effects exerted by the dominant follicle on the subordinate follicles (Hagemann et al., 1999). Comparative gene expression analysis of oocytes from growth and dominance phases (Ghanem et al., 2007.) revealed a total of 51 differentially regulated genes proving a transcriptional difference in bovine oocytes derived from small follicles at growth versus dominance phases. However, these transcripts need to be further evaluated to understand their precise role in defining the differences in oocyte competence with regards to specific differentiation states.

Chromatin configuration is another trademark of oocyte competence. Germinal vesicle oocytes possess different states of chromatin condensation. In particular, they can be observed either with a non-surrounded nucleolus (NSN) configuration, which is associated with low oocyte competence, or with a surrounded nucleolus (SN) configuration, which is associated with high competence and a condensed chromatin, which reflects a repressed transcriptional state (Zuccotti et al., 1995; Tan et al., 2009). Compared with SN oocytes, NSN oocytes display a higher gene transcription activity and a lower rate of meiosis resumption ( $\mathrm{G} 2 / \mathrm{M}$ transition), and they are mostly arrested at the two-cell stage after in vitro fertilization. Another study (Zuccotti et al., 2008) evaluated the differences in gene expression between these two chromatin configurations in mouse oocytes at the metaphase II stage. The study identified, 303 genes over expressed and 77 under expressed genes in NSN oocytes. Once again, as in the study of Pan et al. (2005), there was a greater proportion of genes over expressed in the non-competent oocyte group. However, these findings are controversial. In fact, a study found that $\mathrm{SN}$, competent, mouse oocytes had a greater proportion of over expressed genes (459 transcripts) compared to the NSN, non-competent, group that had only 19 overexpressed genes (Monti et al., 2013). Furthermore, a second study did a similar comparison but used RNAseq, instead of microarray analysis (Ma et al. 2013). Consistently with the first study the SN group showed a larger group of upregulated genes (627 transcripts) compared to the NSN group (332 transcripts). However, consistent with another study (Labrecque et al., 2016) the genes that are downregulated as competence acquisition proceeds are related to transcription.

Even if follicle size, differentiation state, maturation and oocyte chromatin configuration are routinely used to select the most competent oocyte and have, therefore, been used as a guide to determine the competent oocyte's transcriptome, concentrating only on competent oocyte morphology may lead to an incorrect picture. In fact, an essential component is missing in all these studies: the direct relationship with the animal's fertility in vivo. The in vivo influence on the oocytes transcriptome and oocyte competence may be completely unrelated to known biological markers mentioned until now. The oocyte may undergo transcriptional changes that are influenced by the individual's environmental condition and may not show up morphologically for example by changes in follicle size or chromatin condensation state. This aspect was recently addressed (Bocchi et al., 2016a, b) by comparing the transcriptome of oocytes collected by ovum pick-up from animals with different fertility. The oocytes were derived from either fertile heifers or from repeat breeders. The transcriptome was analyzed by RNA-seq differential expression analysis and an effective and indubitable difference was found in the transcriptome blueprint of the oocytes derived from heifers and repeat breeders. In particular, this transcriptomic approach revealed differential representation in 42 genes, which were consistently differentially expressed between fertile and infertile individuals. Furthermore, there was a higher number of genes over expressed in the oocytes from the repeat breeder compared to oocytes from fertile individuals. This suggests the occurrence of an uncontrolled expression of the correct gene pattern or a specific response to adverse environmental conditions.

\section{Small RNAs in ovarian function and oocyte competence}

MiRNAs are involved in controlling both female and male reproductive functions. In the female side, they are regulated by a paracrine or autocrine signalling, and are produced by a wide array of cells including oocytes, embryos, endometrial and granulosa cells (Kang et al., 2012; Ponsuksili et al., 2014). Moreover, they are found in biological fluids, such as plasma, serum, follicular or oviductal fluids; they can be freely circulating stable molecules (Sohel et al., 2013) or enclosed in exosomes (Cleys et al., 2014; Kambe et al., 2014). The extracellular miRNAs may be taken up by specific cells of endometrium, placenta or ovarian follicles, where they bind to their target mRNAs, repressing their translation and modulating cellular events and functions (Sohel et al., 2013; Kridli et al., 2015; Mitchell et al., 2015).

Several studies have reported that a number of miRNAs are involved in murine granulosa cell proliferation (Yao et al., 2010; Yan et al., 2012) and estradiol production (Yin et al., 2012). Similar observations were made in porcine granulosa cells where miRNAs regulate estradiol production and apoptosis (Xu et al., 2011; Lin et al., 2012). Furthermore, miRNAs have also been detected in ovine granulosa and theca cells at different stages of follicle development (McBride et al., 2012); in equine ovaries, they play a role in the regulation of cell survival, steroidogenesis, and follicle differentiation (Schauer et al., 2013). In cattle, there are a few examples of a differential expression of miRNAs in granulosa cells during folliculogenesis (Zielak-Steciwko et al., 2014; Gebremedhn et al., 2015).

\section{Small RNAs in folliculogenesis}

In several species, small RNAs regulate gene 
expression post-trascription, during folliculogenesis (Christenson, 2010; Gebremedhn et al., 2015; Khan et $a l ., 2015)$ and the role of miRNAs has been studied with particular interest. Cellular differentiation, which occurs during follicular development, seems to be regulated by the expression and interaction of many miRNAs in a spatio-temporal manner in the different follicle compartments: granulosa (Hatzirodos et al., 2014a, b) and theca cells (Hatzirodos et al., 2014b), follicular fluid and oocyte (Bonnet et al., 2008).

Individual miRNAs take part in folliculogenesis contributing to the regulation of ovarian steroid hormones, targeting hormone receptors as well as modulating hormone biosynthesis and release. For instance, miR-378 is positively linked to aromatase expression and estradiol (E2) synthesis in granulosa cells (Xu et al., 2011). Moreover, miR-133b stimulates ovarian estradiol synthesis by targeting Foxl2, which mediates the transcriptional repression of steroidogenic acute regulatory protein (STAR) and cytochrome P450 family 19 subfamily A member 1 (CYP19A1) to promote E2 biosynthesis (Dai et al., 2013). In addition, miR-383 promotes E2 byosintesis in ovarian granulosa cells. It inhibits RNA binding motif single-stranded interacting protein 1 (RBMS1) altering its mRNA stability and leading to the inactivation of $\mathrm{v}$-myc avian myelocytomatosis viral oncogene homolog (c-Myc), which induces steroidogenesis in these cells (Yin et al., 2012). Finally, miR-423-5p and miR-378 regulate E2 synthesis by targeting CYP19A1 mRNA and repressing CYP19A1 protein content and enzyme activity in newborn piglets (Sui et al., 2014).

In addition to the expression of individual miRNAs, there are subsets of miRNAs, such as the miR-183 cluster and the miR-132 cluster, which are organized in genomic groups and are differentially expressed during different phases of folliculogenesis by specific cells of follicle. This indicates that they have a functional role in granulosa cells during follicular development (Gebremedhn et al., 2015). However, only a small set of miRNAs, among the large number of those expressed, is found to be specific for single follicle stages, while the majority of miRNAs $(>80 \%)$ are expressed at all stages (Gebremedhn et al., 2015). This indicates that commonly expressed miRNAs may play a role in maintaining normal physiological ovarian function during all the follicular phases of the oestrus cycle. Information on stage specific miRNAs may help to decipher the molecular mechanisms of follicular development, ovulation and atresia.

Finally, follicular fluid miRNAs have been recently identified in cattle. In particular, their profiles can be different between developing and mature oocytes. Moreover, differences can be associated also with several miRNAs, which are present as free- or as exosome-vehiculated forms (Sohel et al., 2013). MiRNAs present at different stages may be associated with the growth status of the oocyte and may act as regulators of its developmental competence, by facilitating cell-to-cell communication in the follicle (Sohel et al., 2013). Interestingly, we found that follicular fluid miRNAs can be associated with the different oocyte developmental potential in cattle (Pasquariello et al., 2016b). In particular, some overexpressed miRNAs regulate several genes involved in processes apparently not related to folliculogenesis therefore follicular fluid miRNAs may be molecular interlocutors of the developing follicle with the intraand extra- ovarian processes (Fig. 2).

Oocyte development potential: the potential role of small RNAs

MiRNAs, siRNAs and piRNAs are expressed in oocytes of many species at different stages of development (Grivna et al., 2006; Golden et al., 2008; Watanabe et al., 2008; Tesfaye et al., 2009; Xu et al., 2011; Yang et al., 2012a; Abd El Naby et al., 2013). However, only siRNAs seem to have a critical role in oocyte maturation. This has been inferred by comparing the knockout phenotypes of dicer 1 ribonuclease III (Dicer) and DGCR8 microprocessor complex subunit (Dgcr8) mutant mice. Dicer knockout in the oocyte resulted in meiotic arrest with severe spindle and chromosomal segregation defects and loss of both miRNAs and endo-siRNAs, as they are usually processed by Dicer (Murchison et al., 2007; Tang et al., 2007; Suh et al., 2010). In contrast, Dgcr8 knockout does not induce an obvious phenotype, and mRNA levels remain unchanged even though the oocytes are characterized by the loss of miRNAs (Suh et al., 2010). These findings suggest that endosiRNAs, and not miRNAs, may underlie the meiotic defect of Dicer knockout oocytes. Reporter assays using oocytes of Dgcr8 knock out mice have shown siRNA activity in mature oocytes, but little to no miRNA function (Ma et al., 2010). As with mRNA, miRNA expression in mouse shows a dynamic change during oogenesis, where a large proportion of maternal genes are directly or indirectly under miRNA control (Tang et al., 2007).

Finally, miRNA function is suppressed in fully-grown oocytes although miRNA biogenesis is unaffected and miRNA targets are present. The mechanism of such suppression at present is unknown. P-bodies seem to be correlated with miRNA destabilization. P-bodies are discrete cytoplasmic foci that contain proteins involved in mRNA degradation. They are involved in several post-transcriptional processes: mRNA decay, translational repression, nonsense-mediated mRNA decay and RNAi-mediated repression. All four Ago proteins (Eystathioy et al., 2003; Liu et al., 2005; Sen and Blau, 2005), GW182 (Eystathioy et al., 2003) and two RNA helicases $\mathrm{RCK} / \mathrm{p} 54$ (Chu and Rana, 2006) and MOV10 (Meister et al., 2005) have been found in P-bodies, suggesting that miRNA suppression is localized to the P-body. However, it has also been suggested that P-body formation is a consequence rather than the cause of miRNA-mediated gene silencing, because when siRNA or miRNA silencing pathways are blocked, P-bodies are not formed (Eulalio et al., 2007). This hypothesis is supported by the loss of P-bodies in maturing oocytes followed by their resumption at the blastocyst stage 
(Kuramochi-Miyagawa et al., 2004; Parker and Sheth, 2007; Swetloff et al., 2009; Flemr et al., 2010). PiRNAs are also expressed in mouse oocytes (Watanabe et al., 2008), but deletion of the Piwi proteins does not produce an observable oocyte phenotype (Deng and Lin, 2002; Kuramochi-Miyagawa et al., 2004; Eulalio et al., 2007). Therefore, it is unclear whether they play a role in oogenesis.

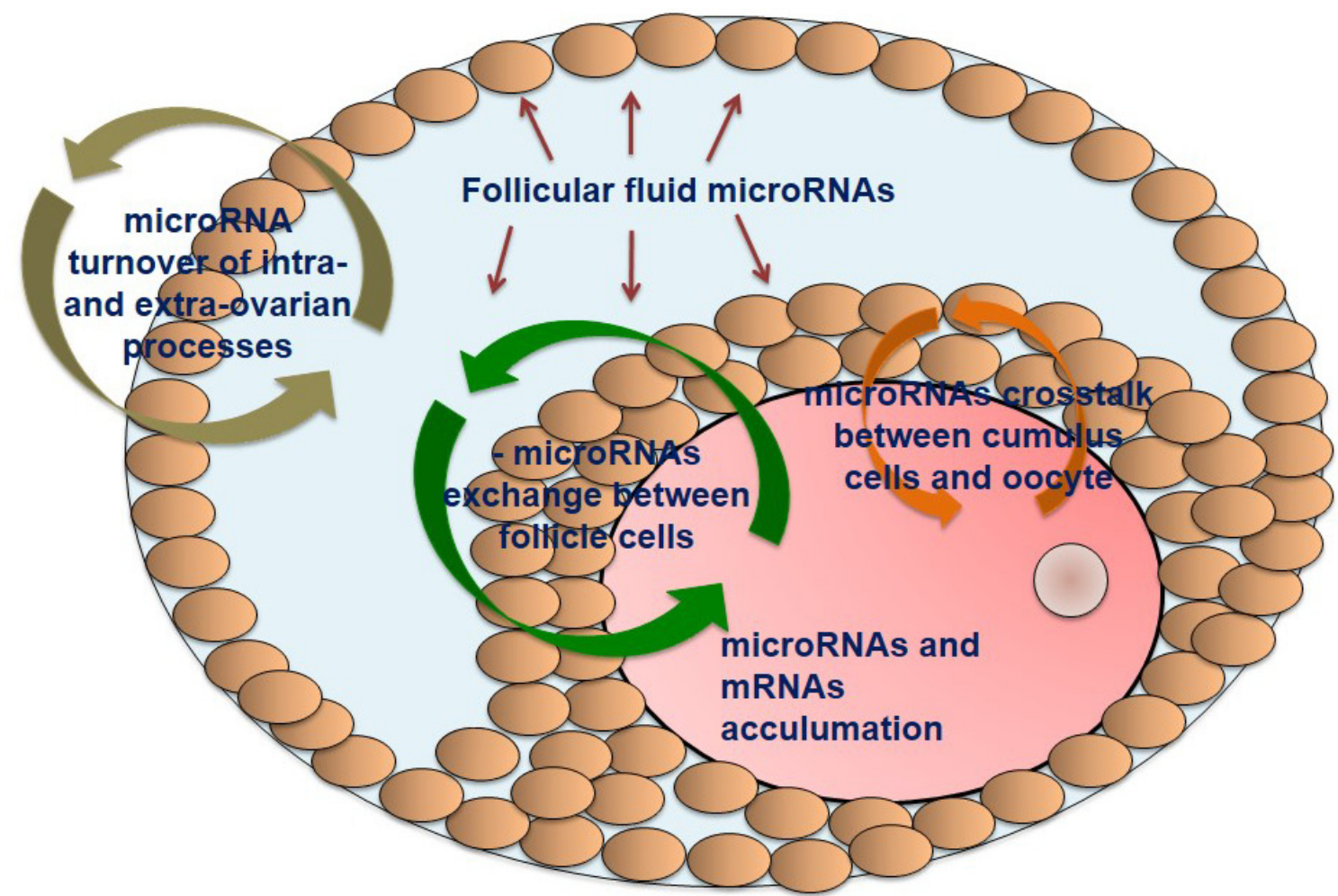

Figure 2. Representation of the microRNAs and mRNAs turnover of mechanisms underlying oocyte development. 1) MicroRNAs may be molecular interlocutors of the developing follicle with the intra- and extra- ovarian processes. 2) Follicular fluid microRNAs are delivered in the follicle antrum by the different compartments of the follicle including the oocyte and its cumulus cells, granulosa and theca cells. 3) Exchange of the microRNAs between the follicular fluid and the oocyte may be a way of communication between the developing oocyte and the follicle. 4) Crosstalk between cumulus cells and the oocyte may come through a microRNA exchange. 5) mRNAs and microRNAs are accumulated in the ooplasm during the oocyte maturation and have been widely used as indicators of the developmental potential, even if it is still missing a better knowledge of which composes of competent oocyte.

\section{Alteration of miRNA expression and implications for female fertility: the data in humans}

Increasing evidences on the role of miRNAs during female reproduction point to an association between these molecules and several diseases, which generally affect oocyte developmental competence (Sirotkin et al., 2010; Roth et al., 2014) at least in humans. Although data in domestic animals are not available yet, it is of interest to consider this aspect as well, since it may have a wider impact than currently perceived.

\section{Polycystic ovarian syndrome (PCOS)}

Polycystic ovarian syndrome (PCOS) is an anovulatory disorder characterized by the development of ovarian cysts and affects women of all reproductive age (Yildiz et al., 2012). The underlying mechanisms resulting in PCOS are not understood, however, the expression of several miRNAs are characteristic of PCOS patients (Sorensen et al., 2014). Using microarray and quantitative PCR, 5 miRNAs (let-7i-3p, miR-5706, miR-4463, miR-3665, miR-638) were found to be overexpressed in the blood of women with PCOS, compared to healthy controls, while 4 (miR-124-3p, miR-128, miR- 29a-3p, let-7c) were underexpressed (Ding et al., 2014). When deep sequencing was used to profile exosomes from the follicular fluid of women with PCOS, miR-132 and miR-320 were found to be less abundant in the follicular fluid compared to controls (Sang et al., 2013). These authors also demonstrate that miR-132 and miR-320 stimulated production of E2 in a human granulosa-like tumor cell line, while inhibition of these miRNAs suppressed E2 production.

In addition to variations in serum and follicular miRNA populations associated with PCOS, miRNAs differences were also observed in the developing embryos of these women, which could have an impact on their developmental competence. Blastocysts derived from oocytes obtained from PCOS patients have an under-regulated subset of miRNAs, like let-7a, miR19a, miR-19b, miR-24, miR-92, and miR-93 (McCallie et al., 2010), which can compromise embryo 
development and, thus, fertility.

\section{Premature ovarian failure (POF)}

Premature ovarian failure (POF) is a disorder with multifactorial origin, which affects ovarian function in women under 40 years of age. The condition is characterized by early ovarian senescence and diminished antral follicle count (AFC; Slopien and Warenik-Szymankiewicz, 2014). Several studies have identified alterations in miRNA levels of women with POF. Interestingly, these studies focused mainly on circulating miRNAs in plasma and serum. miR-22 plasma levels were reduced in women with POF compared with control women. Under-regulation of miR-22 was also correlated with a lower AFC (Dang et al., 2015). Moreover, miRNAs circulating in plasma, which are associated with POF, have important roles in regulating many signaling pathways. miR-23a, which was abundant in the plasma of POF patients inhibits Xlinked inhibitor of apoptosis (XIAP) and caspase-3 expression, resulting in apoptosis in human granulosa cells (Yang et al., 2012). These results indicate that circulating miRNAs can be potentially used as noninvasive biomarkers of POF.

Interestingly, Single-Nucleotide Polymorphisms (SNPs) are found in genomic DNA coding for miRNAs, which have been associated with disease susceptibility. A study of miRNA polymorphisms identified an association between combined genotypes in the genome coding for miR-146aC $>\mathrm{G}$, miR-196a2T $>C$, and miR$499 \mathrm{~A}>\mathrm{G}$ and $\mathrm{POF}$ in women. Therefore transcriptional changes in miR-146a and miR-196a2 induced by miRNA SNPs may be involved in POF development (Rah et al., 2013).

\section{Conclusions}

An indispensable prerequisite for the development of a healthy offspring is to fertilize a competent oocyte. However, the unraveling of the long building process for obtaining a competent oocyte is still in progress. Recent technical and conceptual advances allow a better understanding of ovarian function and oocyte development, but the precise definition of the blueprint of a competent oocyte is still to come. This unquestionably remains a very valuable target because fertility remains a key element for sustaining an efficient animal production that is crucial for providing affordable food to a growing population. It will also be necessary to understand how to increase resilience to the increasingly adverse environmental conditions that are forecast as a consequence of global warming. The task is complex and requires extensive resources that are difficult to raise. Therefore, substantial progress in the field will benefit from a global effort from a global scientific community willing to standardize procedures and pool large databases.

\section{Acknowledgments}

The work of the authors was supported by
MUST Prin 2008 and Fecund project (FP7-KBBE2012- FECUND-312097).

\section{References}

Abd El Naby WS, Hagos TH, Hossain MM, SalilewWondim D, Gad AY, Rings F, Cinar MU, Tholen E, Looft C, Schellander K, Hoelker M, Tesfaye D. 2013. Expression analysis of regulatory microRNAs in bovine cumulus oocyte complex and preimplantation embryos. Zygote, 21:31-51.

Adams GP. 1999. Comparative patterns of follicle development and selection in ruminants. $J$ Reprod Fertil Suppl, 54:17-32.

Andreas E, Hoelker M, Neuhoff C, Tholen E, Schellander K, Tesfaye D, Salilew-Wondim D. 2016. MicroRNA 17-92 cluster regulates proliferation and differentiation of bovine granulosa cells by targeting PTEN and BMPR2 genes. Cell Tissue Res. doi: 10.1007/s00441-016-2425-7.

Antoniou E, Taft R. 2012. Gene expression in mouse oocytes by RNA-Seq. Methods Mol Biol, 825:237-51.

Arlotto T, Schwartz JL, First NL, Leibfried Rutledge ML. 1996. Aspects of follicle and oocyte stage that affect in vitro maturation and development of bovine oocytes. Theriogenology, 45:943-956.

Babiarz JE, Ruby JG, Wang Y, Bartel DP, Blelloch R. 2008. Mouse ES cells express endogenous shRNAs, siRNAs, and other microprocessor- independent, Dicerdependent small RNAs. Genes Dev, 22:2773-2785.

Banerjee S, Saraswat G, Bandyopadhyay SA, Kabir SN. 2014. Female reproductive aging is master planned at the level of ovary. PLoS One, 9:e96210.

Blondin P, Sirard MA. 1995. Oocyte and follicular morphology as determining characteristics for developmental competence in bovine oocytes. Mol Reprod Dev, 41:54-62.

Bocchi V, Strillacci MG, Zecconi A, Galli C, Stradaioli G, Brevini TAL, Bagnato A, Gandolfi F. 2016a. Searching for the in vivo transcriptome blueprint of competent bovine oocytes. Reprod Fertil Dev, 28:226-227.

Bocchi V, Strillacci MG, Zecconi A. Galli C, Stradaioli G, Brevini TAL, Bagnato A, Gandolfi F. 2016b. Searching through the transcriptome of in vivo bovine oocytes led to the identification of 12 genes associated with high fertility. In: Proceedings 18th International Congress of Animal Reproduction, Tours, France. Tours, France: ICAR. pp. 249-250. (abstract).

Bonnet A, Dalbies-Tran R, Sirard MA. 2008. Opportunities and challenges in applying genomics to the study of oogenesis and folliculogenesis in farm animals. Reproduction, 135:119-128.

Brevini TAL, Favetta LA, Mauri L, Luciano AM, Cillo F, Gandolfi F. 1999. Changes in poly(A) tail length of maternal transcripts during in vitro maturation of bovine oocytes and their relation with developmental competence. Mol Reprod Dev, 52:427-433.

Brevini TAL, Gandolfi F. 2001. The maternal legacy to the embryo: cytoplasmic components and their effects on early development. Theriogenology, 55:12551276. 
Brevini TAL, Lonergan P, Cillo F, Francisci C, Favetta LA, Fair T, Gandolfi F. 2002. Evolution of mRNA polyadenylation between oocyte maturation and first embryonic cleavage in cattle and its relation with developmental competence. Mol Reprod Dev, 63:510517

Brevini TAL, Vassena R, Francisci C, Gandolfi F. 2005. Role of adenosine triphosphate, active mitochondria and microtubules in the acquisition of developmental competence of parthenogenetically activated pig oocytes. Biol Reprod, 72:1218-1223.

Brevini TAL, Cillo F, Antonini S, Tosetti V, Gandolfi F. 2007. Temporal and spatial control of gene expression in early embryo of farm animals. Reprod Fertil Dev, 16:35-42.

Bultman SJ, Gebuhr TC, Pan H, Svoboda P, Schultz RM, Magnuson T. 2006. Maternal BRG1 regulates zygotic genome activation in the mouse. Genes Dev, 20:1744-1754.

Carletti MZ, Fiedler SD, Christenson LK. 2010. microRNA 21 blocks apoptosis in mouse periovulatory granulosa cells. Biol Reprod, 83:286-295.

Cleys ER, Halleran JL, McWhorter E, Hergenreder J, Enriquez VA, da Silveira JC, Bruemmer JE, Winger QA, Bouma GJ. 2014. Identification of microRNAs in exosomes isolated from serum and umbilical cord blood, as well as placentomes of gestational day 90 pregnant sheep. Mol Reprod Dev, 81:983-993.

Cran DG. 1989. Cortical granules during oocyte maturation and fertilization. $J$ Reprod Fertil, 38:49-62.

Chitwood JL, Rincon G, Kaiser GG, Medrano JF, Ross PJ. 2013. RNA-seq analysis of single bovine blastocysts. BMC Genomics, 14:350.

Christenson LK. 2010. MicroRNA control of ovarian function. Anim Reprod, 7:129-133.

Chu CY, Rana TM. 2006. Translation repression in human cells by microRNA-induced gene silencing requires RCK/p54. PLoS Biol, 4:e210.

Da Silveira JC, Veeramachaneni DNR, Winger QA, Carnevale EM, Bouma GJ. 2012. Cell-secreted vesicles in equine ovarian follicular fluid contain miRNAs and proteins: A possible new form of cell communication within the ovarian follicle. Biol Reprod, 86:71. doi: 10.1095/biolreprod.111.093252.

Dai A, Sun H, Fang T, Zhang Q, Wu S, Jiang Y, Ding L, Yan G, Hu Y. 2013. MicroRNA-133b stimulates ovarian estradiol synthesis by targeting Fox12. FEBS Lett, 587:2474-2482.

Dalbiès-Tran R, Mermillod P. 2003. Use of heterologous complementary DNA array screening to analyze bovine oocyte transcriptome and its evolution during in vitro maturation. Biol Reprod, 68:252-61.

Dang Y, Zhao S, Qin Y, Han T, Li W, Chen ZJ 2015. MicroRNA-22-3p is down- regulated in the plasma of Han Chinese patients with premature ovarian failure. Fertil Steril, 103:802-807.

Deng W, Lin H. 2002. Miwi, a murine homolog of piwi, encodes a cytoplasmic protein essential for spermatogenesis. Dev Cell, 2:819-830.

Ding CF, Chen WQ, Zhu YT, Bo YL, Hu HM, Zheng RH. 2014. Circulating microRNAs in patients with polycystic ovary syndrome. Hum Fertil, 18:22-29.

Donadeu FX, Schauer SN. 2013. Differential miRNA expression between equine ovulatory and anovulatory follicles. Domest Anim Endocrinol, 45:122-125.

Eulalio A, Behm-Ansmant I, Schweizer D, Izaurralde E. 2007. P-body formation is a consequence, not the cause, of RNA-mediated gene silencing. Mol Cell Biol, 27:3970-3981.

Eystathioy T, Jakymiw A, Chan EK, Seraphin B, Cougot N, Fritzler MJ. 2003. The GW182 protein colocalizes with mRNA degradation associated proteins hDcp1 and hLSm4 in cytoplasmic GW bodies. RNA, 9:1171-1173

Fair T, Hyttel P, Greve T. 1995. Bovine oocyte diameter in relation to maturational competence and transcriptional activity. Mol Reprod Dev, 42:437-442.

Fair T, Hyttel P, Greve T, Boland M. 1996. Nucleus structure and transcriptional activity in relation to oocyte diameter in cattle. Mol Reprod Dev, 43:503-512.

Fair T, Hulshof SCJ, Hyttel P, Greve T, Boland M. 1997. Oocyte ultrastructure in bovine primordial to tertiary follicles. Anat Embryol, 195:327-336.

Fair T, Carter F, Park S, Evans AC, Lonergan P. 2007. Global gene expression analysis during bovine oocyte in vitro maturation. Theriogenology, 68(suppl. 1):S91-97.

Fiedler SD, Carletti MZ, Hong X, Christenson LK. 2008. Hormonal regulation of microRNA expression in periovulatory mouse mural granulosa cells. Biol Reprod, 79:1030-1037

Flemr M, Ma J, Schultz RM, Svoboda P. 2010. Pbody loss is concomitant with formation of a messenger RNA storage domain in mouse oocytes. Biol Reprod, 82:1008-1017.

Fortune JE, Sirois J, Turzillo AM, Lavoir M. 1991. Follicle selection in domestic ruminants. J Reprod Fertil Suppl, 43:187-198.

Fouladi-Nashta A, Gutierrez C, Garnsworthy $\mathbf{P}$, Webb R. 2005. Effects of dietary carbohydrate source on oocyte/embryo quality and development in highyielding, lactating dairy cattle. Biol Reprod Special Issue:135-136. (abstract).

Friedlä nder MR, Mackowiak SD, Li N, Chen W, Rajewsky N. 2012. miRDeep2 accurately identifies known and hundreds of novel microRNA genes in seven animal clades. Nucleic Acids Res, 40:37-52.

Gandolfi F, Luciano AM, Modina S, Ponzini A, Pocar P, Armstrong DT, Lauria A. 1997. The in vitro developmental competence of bovine oocytes can be related to the morphology of the ovary. Theriogenology, 48:1153-1160.

Gandolfi F, Lauria A, Enne G, Gianaroli L. 1998a. Embryonic development as a function of oocyte competence. In: Lauria A, Gandolfi F, Enne G, Gianaroli I (Ed.). Gametes Development and Function. Rome: Serono Symposia. pp. 337-353.

Gandolfi F, Milanesi E, Pocar P, Luciano AM, Brevini TA, Acocella F, Lauria A, Armstrong DT. 1998b. Comparative analysis of calf and cow oocytes during in vitro maturation. Mol Reprod Dev, 49:168175.

Gebremedhn S, Salilew-Wondim D, Ahmad I, 
Sahadevan S, Hossain MM, Hoelker M, Rings F, Neuhoff C, Tholen E, Looft C, Schellander $\mathbf{K}$, Tesfaye D. 2015. MicroRNA expression profile in bovine granulosa cells of preovulatory dominant and subordinate follicles during the late follicular phase of the estrous cycle. PLoS One, 10:1-26.

Gebremedhn S, Salilew-Wondim D, Hoelker M, Rings F, Neuhoff C, Tholen E, Schellander K, Tesfaye D. 2016. MicroRNA-183-96-182 Cluster regulates bovine granulosa cell proliferation and cell cycle transition by coordinately targeting FOXO1. Biol Reprod, 94:127. doi: 10.1095/biolreprod.115.137539. Gendelman M, Roth Z. 2012. Seasonal effect on germinal vesicle stage bovine oocytes is further expressed by alterations in transcript levels in the developing embryos associated with reduced developmental competence. Biol Reprod, 86:1-9.

Ghanem N, Holker M, Rings F, Jennen D, Tholen E, Sirard MA, Torner H, Kanitz W, Schellander K, Tesfaye D. 2007. Alterations in transcript abundance of bovine oocytes recovered at growth and dominance phases of the first follicular wave. BMC Dev Biol, 7:90.

Gilchrist GC, Tscherner A, Nalpathamkalam T, Merico D, LaMarre J. 2016. MicroRNA expression during bovine oocyte maturation and fertilization. Int $J$ Mol Sci, 17:396. doi: 10.3390/ijms17030396.

Golden DE, Gerbasi VR, Sontheimer EJ. 2008. An inside job for siRNAs. Mol Cell, 31:309-312.

Gougeon A. 1986. Dynamics of follicular growth in the human: a model from preliminary results. Hum Reprod, 1:81-87.

Graf A, Krebs S, Zakhartchenko V, Schwalb B, Blum H, Wolf E. 2014. Fine mapping of genome activation in bovine embryos by RNA sequencing. Proc Natl Acad Sci USA, 111:4139-4144.

Grivna ST, Beyret E, Wang Z, Lin H. 2006. A novel class of small RNAs in mouse spermatogenic cells. Genes Dev, 20:1709-1714.

Hagemann LJ, Beaumont SE, Berg M, Donnison MJ, Ledgard A, Peterson AJ, Schurmann A, Tervit HR. 1999. Development during single IVP of bovine oocytes from dissected follicles: interactive effects of estrous cycle stage, follicle size and atresia. Mol Reprod Dev, 53:451-458.

Hatzirodos N, Hummitzsch K, Irving-Rodgers HF, Harland ML, Morris SE, Rodgers RJ. 2014a Transcriptome profiling of granulosa cells from bovine ovarian follicles during atresia. BMC Genomics, 15:1471-2164.

Hatzirodos N, Hummitzsch K, Irving-Rodgers HF, Rodgers RJ. 2014b. Transcriptome profiling of the theca interna in transition from small to large antral ovarian follicles. PLoS One; 9:e97489.

Hyttel P, Fair T, Callesen H, Greve T. 1997. Oocyte growth, capacitation and final maturation in cattle. Theriogenology, 47:23-32.

Hyttel P, Viuff D, Fair T, Laurincik J, Thomsen PD, Callesen H, Vos PL, Hendriksen PJ, Dieleman SJ, Schellander K, Besenfelder U, Greve T. 2001 Ribosomal RNA gene expression and chromosome aberrations in bovine oocytes and preimplantation embryos. Reproduction, 122:21-30.
Ishizu H, Siomi H, Siomi MC. 2012. Biology of PIWIinteracting RNAs: new insights into biogenesis and function inside and outside of germlines. Genes Dev, 26:2361-2373

Juliano C, Wang J, Lin H. 2011. Uniting germline and stem cells: the function of Piwi proteins and the piRNA pathway in diverse organisms. Annu Rev Genet, 45:447469.

Kambe S, Yoshitake H, Yuge K, Ishida Y, Ali MM2, Takizawa T, Kuwata T, Ohkuchi A, Matsubara S, Suzuki M, Takeshita T, Saito S, Takizawa T. 2014. Human exosomal placenta-associated miR-517a-3p modulates the expression of PRKG1 mRNA in Jurkat cells. Biol Reprod, 91:129. doi: 10.1095/biolreprod.114.121616.

Kang JT, Atikuzzaman M, Kwon DK, Park SJ, Kim SJ, Moon JH, Koo OJ, Jang G, Lee BC. 2012. Developmental competence of porcine oocytes after in vitro maturation and in vitro culture under different oxygen concentrations. Zygote, 20:1-8.

Khan DR, Fournier É, Dufort I, Richard FJ, Singh J, Sirard MA. 2016. Meta-analysis of gene expression profiles in granulosa cells during folliculogenesis. Reproduction, 151:103-110.

Khan HA, Zhao Y, Wang L, Li Q, Du YA, Dan Y, Huo LJ. 2015. Identification of miRNAs during mouse postnatal ovarian development and superovulation. $J$ Ovarian Res, 8:44. doi: 10.1186/s13048-015-0170-2.

Kim VN, Han J, Siomi MC. 2009. Biogenesis of small RNAs in animals. Nat Rev Mol Cell Biol, 10:126-139.

Knight PG, Glister C. 2001. Potential local regulatory functions of inhibins, activins and follistatin in the ovary. Reproduction, 121:503-512.

Kozomara A, Griffiths-Jones S. 2014. miRBase: annotating high confidence microRNAs using deep sequencing data. Nucleic Acids Res, 42(database issue):D68-73

Kridli RT, Khalaj K, Bidarimath M, Tayade C. 2015. Placentation, maternal-fetal interface, and conceptus loss in swine. Theriogenology, 85:135-144.

Kuramochi-Miyagawa S, Kimura T, Ijiri TW, Isobe T, Asada N, Fujita Y, Ikawa M, Iwai N, Okabe M, Deng W, Lin H, Matsuda Y, Nakano T. 2004. Mili, a mammalian member of piwi family gene, is essential for spermatogenesis. Development, 131:839-849.

Labrecque R, Sirard MA. 2014. The study of mammalian oocyte competence by transcriptome analysis: progress and challenges. Mol Hum Reprod, 20:103-16.

Labrecque R, Lodde V, Dieci C, Tessaro I, Luciano AM, Sirard MA. 2015. Chromatin remodelling and histone mRNA accumulation in bovine germinal vesicle oocytes. Mol Reprod Dev, 82:450-462.

Labrecque R, Fournier E, Sirard MA. 2016. Transcriptome analysis of bovine oocytes from distinct follicle sizes: Insights from correlation network analysis. Mol Reprod Dev, 83:558-569.

Leroy JL, Opsomer G, Van Soom A, Goovaerts I, Bols P. 2008. Reduced fertility in high-yielding dairy cows: are the oocyte and embryo in danger? Part I the importance of negative energy balance and altered corpus luteum function to the reduction of oocyte and 
embryo quality in high-yielding dairy cows. Reprod Domest Anim, 43:612-622.

Levesque JT, Sirard MA. 1995. Effects of different kinases and phosphatases on nuclear and cytoplasmic maturation of bovine oocytes. Mol Reprod Dev, 42:114121.

Lin F, Li R, Pan ZX, Zhou B, Yu DB, Wang XG, Ma XS, Han J, Shen M, Liu HL. 2012. miR-26b promotes granulosa cell apoptosis by targeting ATM during follicular atresia in porcine ovary. PLoS One, 7:e38640.

Liu J, Valencia-Sanchez MA, Hannon GJ, Parker R 2005. MicroRNA-dependent localization of targeted mRNAs to mammalian P-bodies. Nat Cell Biol, 7:719723

Lonergan P, Gutierrez-Adan A, Rizos D, Pintalo B, De La Fuente J, Boland MP. 2003. Relative messenger RNA abundance in bovine oocytes collected in vitro or in vivo before and $20 \mathrm{hr}$ after the preovulatory luteinizing hormone surge. Mol Reprod Dev, 66:297-305.

Ma J, Zeng F, Schultz RM, Tseng H. 2006 Basonuclin: a novel mam- malian maternal-effect gene. Development, 133:2053-2062.

Ma J, Flemr M, Stein $\mathbf{P}$, Berninger $\mathbf{P}$, Malik $\mathbf{R}$, Zavolan M, Svoboda P, Schultz RM. 2010 MicroRNA activity is suppressed in mouse oocytes. Curr Biol. 20:265-270.

Ma JY, Li M, Luo YB, Song S, Tian D, Yang J, Zhang B, Hou Y, Schatten H, Liu Z, Sun QY. 2013. Maternal factors required for oocyte developmental competence in mice: Transcriptome analysis of nonsurrounded nucleolus (NSN) and surrounded nucleolus (SN) oocytes. Cell Cycle, 12:1928-1938.

Ma T, Jiang H, Gao, Y, Zhao Y, Dai L, Xiong Q, Xu Y, Zhao Z, Zhang J. 2011. Microarray analysis of differentially expressed microRNAs in non-regressed and regressed bovine corpus luteum tissue: MicroRNA378 may suppress luteal cell apoptosis by targeting the interferon gamma receptor 1 gene. $J$ Appl Genet, 52:481-486

McBride D, Carre W, Sontakke S, Hogg CO, Law AS, Donadeu FX, Clinton M. 2012. Identification of miRNAs associated with the follicular-luteal transition in the ruminant ovary. Reproduction, 144:221-233.

McCallie B, Schoolcraft WB, Katz-Jaffe MG. 2010 Aberration of blastocyst microRNA expression is associated with human infertility. Fertil Steril, 93:23742382.

McGettigan PA, Browne JA, Carrington SD, Crowe MA, Fair T, Forde N, Loftus BJ, Lohan A, Lonergan P, Pluta K, Mamo S, Murphy A, Roche J, Walsh SW, Creevey CJ, Earley B, Keady S, Kenny DA, Matthews D, McCabe M, Morris D, O'Loughlin A, Waters S, Diskin MG, Evans AC. 2015. Fertility and genomics: comparison of gene expression in contrasting reproductive tissues of female cattle. Reprod Fertil Dev, 28:11-24.

Meister G, Landthaler M, Peters L, Chen PY, Urlaub H, Luhrmann R, Tuschl T. 2005 Identification of novel argonaute-associated proteins. Curr Biol, 15:2149-2155.

Milazzotto MP, Feitosa WB, Paula-Lopes FF,
Buratini J Jr, Visintin JA, Assumpção ME. 2012. The mechanism of oocyte activation influences the cell cycle-related genes expression during bovine preimplantation development. Cell Reprogram, 14:41824.

Mitchell MD, Peiris HN, Kobayashi M, Koh YQ, Duncombe G, Illanes SE, Rice GE, Salomon C. 2015. Placental exosomes in normal and complicated pregnancy. Am J Obstet Gynecol, 213(suppl):S173-181. Mondou E, Dufort I, Gohin M, Fournier E, Sirard MA. 2012. Analysis of microRNAs and their precursors in bovine early embryonic development. Mol Hum Reprod, 18:425-434.

Monti M, Zanoni M, Calligaro A, Ko MS, Mauri P, Redi CA. 2013. Developmental arrest and mouse antral not-surrounded nucleolus oocytes. Biol Reprod, 88:2. doi: 10.1095/biolreprod.112.103887.

Mourot M, Dufort I, Gravel C, Algriany O, Dieleman S, Sirard MA. 2006. The influence of follicle size, FSH-enriched maturation medium, and early cleavage on bovine oocyte maternal mRNA levels. Mol Reprod Dev, 73:1367-1379.

Murchison EP, Stein P, Xuan Z, Pan H, Zhang MQ, Schultz RM, Hannon GJ. 2007. Critical roles for dicer in the female germline. Genes Dev, 21:682-693.

Pan H, O'Brien MJ, Wigglesworth K, Eppig JJ, Schultz RM. 2005. Transcript profiling during mouse oocyte development and the effect of gonadotropin priming and development in vitro. Dev Biol, 286:493506.

Parker R, Sheth U. 2007. P bodies and the control of mRNA translation and degradation. Mol Cell, 25:635646.

Pasquariello R, Fernandez-Fuertes B, Strozzi B, Pizzi B, Mazza R, Lonergan P, Gandolfi F, Williams JL. 2016a. Profiling bovine blastocyst microRNAs using deep sequencing. Reprod Fertil Dev. (in press). doi:10.1071/RD16110

Pasquariello R, Fiandanese N, Viglino A, Pocar P, Williams JL, Gandolfi F. 2016b. Follicular fluid microRNA sequences as biomarkers of competent oocytes in cattle. Reprod Fertil Dev, 28:204-204.

Philipps DL, Wigglesworth K, Hartford SA, Sun F, Pattabiraman S, Schimenti K, Handel M, Eppig JJ, Schimenti JC. 2008. The dual bromodomain and WD repeat-containing mouse protein BRWD1 is required for normal spermiogenesis and the oocyte-embryo transition. Dev Biol, 317:72-82.

Pocar P, Brevini TAL, Antonini S, Gandolfi F. 2006. Cellular and molecular mechanisms mediating the effect of polychlorinated byphenils in occytes in vitro maturation. Reprod Toxicol, 22:242-249.

Ponsuksili S, Tesfaye D, Schellander K, Hoelker M, Hadlich F, Schwerin M, Wimmers K. 2014. Differential expression of miRNAs and their target mRNAs in endometria prior to maternal recognition of pregnancy associates with endometrial receptivity for in vivo- and in vitro-produced bovine embryos. Biol Reprod, 91:135-145.

Rah H, Jeon YJ, Shim SH, Cha SH, Choi DH, Kwon H, Kim JH, Shin JE, Kim NK. 2013. Association of miR-146aC $>$ G, miR-196a2T $>C$, and miR-499A $>$ G 
polymorphisms with risk of premature ovarian failure in Korean women. Reprod Sci, 20:60-68.

Reyes JM, Chitwood JL, Ross PJ. 2015. RNA-Seq profiling of single bovine oocyte transcript abundance and its modulation by cytoplasmic polyadenylation. Mol Reprod Dev, 82:103-114.

Rooke J, Ainslie A, Watt R, Alink F, McEvoy T, Sinclair K, Garnsworthy P, Webb R. 2009. Dietary carbohydrates and amino acids influence oocyte quality in dairy heifers. Reprod Fertil Dev, 21:419-427.

Roth LW, McCallie B, Alvero R, Schoolcraft WB, Minjarez D, Katz-Jaffe MG. 2014. Altered microRNA and gene expression in the follicular fluid of women with polycystic ovary syndrome. $J$ Assist Reprod Genet, 31:355-362.

Sang, Q, Yao Z, Wang H, Feng R, Wang H, Zhao, X, Xing Q, Jin L, He L, Wu L, Wang L. 2013. Identification of microRNAs in human follicular fluid: characterization of microRNAs that govern steroidogenesis in vitro and are associated with polycystic ovary syndrome in vivo. $J$ Clin Endocrinol Metab, 98:3068-3079.

Schauer SN, Sontakke SD, Watson ED, Esteves CL, Donadeu FX. 2013. Involvement of miRNAs in equine follicle development. Reproduction, 146:273-282.

Sen GL and Blau HM. 2005. Argonaute 2/RISC resides in sites of mammalian mRNA decay known as cytoplasmic bodies. Nat Cell Biol, 7:633-636.

Sirard MA, Florman HM. Leibfried-Rutledge, ML, Barnes FL, Sims ML, First NL. 1989. Timing of nuclear progression and protein synthesis necessary for meiotic maturation of bovine oocytes, Biol Reprod, 40:1257-1263.

Sirard MA, Richard F, Blondin P, Robert C. 2006 Contribution of the oocyte to embryo quality. Theriogenology, 65:126-136.

Sirotkin AV, Ovcharenko D, Grossmann R, Lauková M, Mlyncek M. 2009. Identification of microRNAs controlling human ovarian cell steroidogenesis via a genome-scale screen. J Cell Physiol, 219:415-420.

Sirotkin AV, Lauková M, Ovcharenko D, Brenaut P, Mlyncek M. 2010. Identification of microRNAs controlling human ovarian cell proliferation and apoptosis. J Cell Physiol, 223:49-56.

Slopien R, Warenik-Szymankiewicz A. 2014 Premature ovarian failure: diagnosis and treatment. Clin Exp Obstet Gynecol, 41:659-661.

Snijders S, Dillon P, O'Callaghan D, Boland $M$. 2000. Effect of genetic merit, milk yield, body condition and lactation number on in vitro oocyte development in dairy cows. Theriogenology, 53:981-989.

Sohel MM, Hoelker M, Noferesti SS, SalilewWondim D, Tholen E, Looft C, Rings F, Uddin MJ, Spencer TE, Schellander K, Tesfaye D. 2013. Exosomal and non-exosomal transport of extra-cellular microRNAs in follicular fluid: implications forbovine oocyte developmental competence. PLoS One, 8:e78505.

Sontakke SD, Mohammed BT, McNeilly AS, Donadeu FX. 2014. Characterization of microRNAs differentially expressed during bovine follicle development. Reproduction, 148:271-283.
Sorensen AE, Wissing ML, Salo S, Englund AL, Dalgaard LT. 2014. MicroRNAs related to poly- cystic ovary syndrome (PCOS). Genes (Basel), 5:684-708.

Sorensen RA, Wassarman PM. 1976. Relationship between growth and meiotic maturation of the mouse oocyte. Dev Biol, 50:531-536.

Suh N, Baehner L, Moltzahn F, Melton C, Shenoy A, Chen J, Blelloch R. 2010. MicroRNA function is globally suppressed in mouse oocytes and early embryos. Curr Biol, 20:271-277.

Sui S, Jia Y, He B, Li R, Li X, Cai D, Song H, Zhang R, Zhao R. 2014. Maternal low-protein diet alters ovarian expression of folliculogenic and steroidogenic genes and their regulatory MicroRNAs in neonatal piglets. Asian-Australas J Anim Sci, 27:1695-1704

Swetloff A, Conne B, Huarte J, Pitetti JL, Nef S, Vassalli JD. 2009. Dcp1-bodies in mouse oocytes. Mol Biol Cell, 20:4951-4961.

Tan JH, Wang HL, Sun XS, Liu Y, Sui HS, Zhang J. 2009, Chromatin configurations in the germinal vesicle of mammalian oocytes. Mol Hum Reprod, 15:1-9.

Tang F, Kaneda M, O'Carroll D, Hajkova P, Barton SC, Sun YA, Lee C, Tarakhovsky A, Lao K, Surani MA. 2007. Maternal microRNAs are essential for mouse zygotic development. Genes Dev, 21:644-648.

Telford NA, Watson AJ, Schultz GA. 1990. Transition from maternal to embryonic control in early mammalian development: a comparison of several species. Mol Reprod Dev, 26:90-100.

Tesfaye D, Worku D, Rings F, Phatsara C, Tholen E, Schellander K, Hoelker M. 2009. Identification and expression profiling of microRNAs during bovine oocyte maturation using heterologous approach. Mol Reprod Dev, 76:665-677.

Thomson T, Lin H. 2009. The biogenesis and function of PIWI proteins and piRNAs: progress and prospect. Annu Rev Cell Dev Biol, 25:355-376.

Trapnell C, Pachter L, Salzberg SL. 2009. TopHat: discovering splice junctions with RNA-Seq. Bioinformatics, 25:1105-1111.

Trapnell C, Williams BA, Pertea G, Mortazavi A, Kwan G, van Baren MJ, Salzberg, SL, Wold BJ, Pachter L. 2010. Transcript assembly and quantification by RNA-Seq reveals unannotated transcripts and isoform switching during cell differentiation. Nat Biotechnol, 28:511-515.

Van Hoeck V, Leroy J, Alvarez MA, Rizos D, Gutierrez-Adan A, Schnorbusch K, Bols P, Leese HJ, Sturmey RG. 2013. Oocyte developmental failure in response to elevated nonesterified fatty acid concentrations: mechanistic insights. Reproduction, 145:33-44.

Wassarman PM, Kinloch RA. 1992. Gene expression during oogenesis in mice. Mutat Res, 296:3-15.

Watanabe T, Totoki Y, Toyoda A, Kaneda M, Kuramochi-Miyagawa S, Obata Y, Chiba H, Kohara Y, Kono T, Nakano T, Surani MA, Sakaki Y, Sasaki H. 2008. Endogenous siRNAs from naturally formed dsRNAs regulate transcripts in mouse oocytes. Nature, 453:539-543

Xu S, Linher-Melville K, Yang BB, Wu D, Li J. 2011 Micro-RNA378 (miR-378) regulates ovarian estradiol 
production by targeting aromatase. Endocrinology, 152:3941-3951.

Yan G, Zhang L, Fang T, Zhang Q, Wu S, Jiang Y, Sun H, Hu Y. 2012. MicroRNA-145 suppresses mouse granulosa cell proliferation by targeting activin receptor IB. FEBS Lett, 586:3263-3270.

Yang CX, Du ZQ, Wright EC, Rothschild MF, Prather RS, Ross JW. 2012a. Small RNA profile of the cumulus oocyte complex and early embryos in the pig. Biol Reprod, 87:117. doi: 10.1095/biolreprod.111.096669.

Yang X, Zhou Y, Peng S, Wu L, Lin HY, Wang S, Wang H. 2012b. Differentially expressed plasma microRNAs in premature ovarian failure patients and the potential regulatory function of mir-23a in granulosa cell apoptosis. Reproduction, 144:235-44.

Yao G, Yin M, Lian J, Tian H, Liu L, Li X, Sun F. 2010. MicroRNA-224 is involved in transforming growth factor-beta-mediated mouse granulosa cell proliferation and granulosa cell function by targeting Smad4. Mol Endocrinol, 24:540-551.

Yildiz BO, Bozdag G, Yapici Z, Esinler I, Yarali H 2012. Prevalence, phenotype and cardiometabolic risk of polycystic ovary syndrome under different diagnostic criteria. Hum Reprod, 27:3067-3073.
Yin M, LüM, YaoG, TianH, LianJ, LiuL, Liang M, WangY, Sun F. 2012. Transactivation of microRNA383 by steroidogenic factor-1 promotes estradiol release from mouse ovarian granulosa cells by targeting RBMS1. Mol Endocrinol, 26:1129-1143.

Zeron Y, Ocheretny A, Kedar O, Borochov A, Sklan D, Arav A. 2001. Seasonal changes in bovine fertility: relation to developmental competence of oocytes, membrane properties and fatty acid composition of follicles. Reproduction, 121:447-454.

Zielak-Steciwko AE, Browne JA, McGettigan PA, Gajewska M, Dzięcioł M, Szulc T, Evans AC. 2014. Expression of microRNAs and their target genes and pathways associated with ovarian follicle development in cattle. Physiol Genomics, 46:735-745.

Zuccotti M, Piccinelli A, Rossi PG, Garagna S, Redi CA. 1995. Chromatin organization during mouse oocyte growth. Mol Reprod Dev, 41:479-485.

Zuccotti M, Merico V, Sacchi L, Bellone M, Brink TC, Bellazzi R, Stefanelli M, Redi CA, Garagna S, Adjaye J. 2008. Maternal Oct-4 is a potential key regulator of the developmental competence of mouse oocytes. BMC Dev Biol, 8:97. doi: 10.1186/1471-213X8-97. 